\title{
Dermatophilus chelonae sp. nov., Isolated from Chelonids in Australia
}

\author{
A. M. MASTERS, * T. M. ELLIS, J. M. CARSON, S. S. SUTHERLAND, AND A. R. GREGORY \\ Animal Health Laboratories, Department of Agriculture, South Perth, \\ Western Australia 6151, Australia
}

\begin{abstract}
Three isolates of a previously undescribed Dermatophilus sp. obtained from chelonids (two strains obtained from turtles and one strain obtained from a tortoise) were compared with 30 Dermatophilus congolensis isolates obtained from Australian mammals. The microscopic appearance, the colony morphology, and most biochemical test results for the chelonid isolates were characteristic of the genus Dermatophilus. Our isolates differed from the mammalian $D$. congolensis isolates in a number of cultural characteristics, including faster growth at $27^{\circ} \mathrm{C}$ than at $37^{\circ} \mathrm{C}$, formation of two hemolysis zones around colonies on blood agar at $37^{\circ} \mathrm{C}$ in the presence of $10 \% \mathrm{CO}_{2}$, poor motility, and production of a distinctive odor. The DNA restriction enzyme digestion and protein electrophoresis patterns of our strains were distinct. The electrophoretic mobilities of 11 enzymes differed from the mobilities observed with $D$. congolensis strains. A monoclonal antibody to a surface antigen of an ovine isolate did not react with zoospores or filaments of the chelonid isolates. Biochemical differences between our isolates and $D$. congolensis included the ability of the chelonid isolates to reduce nitrate to nitrite and the fact that the chelonid isolates exhibit collagenase activity in vitro. We propose that the chelonid isolates should be placed in a new species, Dermatophilus chelonae. Strain W16, which was isolated from a nose scab on a snapping turtle, is the type strain; a culture of this strain has been deposited in the American Type Culture Collection as strain ATCC 51576.
\end{abstract}

A skin disease caused by the actinomycete Dermatophilus congolensis affects a wide variety of animal species and occurs throughout the world. This disease is economically important in cattle in tropical regions and in sheep in high-rainfall areas. Dermatophilosis lesions have also been found in goats, horses, deer, gazelles, giraffes, foxes, chamois, Columbian ground squirrels, cottontail rabbits, owl monkeys, polar bears, seals, pigs, and humans (13). To date, there apparently have been no reports of isolations of $D$. congolensis from chelonids, although the organism has been isolated from lizards $(2,23,30)$. It has been reported that there is considerable variation in the colony morphology and cultural characteristics of $D$. congolensis (12). Significant variations in serological, biochemical, and virulence characteristics within the species have also been documented $(1,8,10,12,16,18,19,21,33)$. A study of the variations in the cultural, biochemical, and morphological properties of Australian mammalian isolates of $D$. congolensis was recently undertaken (9). In our study we compared the properties of three isolates obtained from chelonids with the properties of these mammalian $D$. congolensis isolates.

\section{MATERIALS AND METHODS}

Bacterial isolates. Dermatophilus sp. isolates were obtained from an abscess in a tortoise in 1980 (isolate W8), from skin lesions on a turtle in 1982 (isolate W11), and from a nose scab on a snapping turtle in 1987 (isolate $\mathrm{W} 16^{\mathrm{T}}[\mathrm{T}=$ type strain]); all of these isolates were obtained at the Perth Zoo, in Perth, Western Australia. The isolates which we used for restriction enzyme analysis of bacterial DNAs included all of the isolates and reference strains listed by Trott et al. (34).

Cultural characteristics. The isolates were cultured on $9 \%$ bovine blood agar (in Oxoid Columbia agar base no. 2) and were observed after 2 to 3 days of incubation at $37^{\circ} \mathrm{C}$ in the presence of $10 \% \mathrm{CO}_{2}$ and at $27^{\circ} \mathrm{C}$ in the ambient atmosphere. The appearance of cultures in tryptose-phosphate- $10 \%$ ovine serum broth inoculated with a dense suspension of zoospores was recorded after 3 days of incubation at $37^{\circ} \mathrm{C}$ and after additional incubation at room tempera-

* Corresponding author. Mailing address: Animal Health Laboratories, Department of Agriculture Western Australia, Baron-Hay Court, South Perth, WA 6151, Australia. Phone: 09368 3923. Fax: 09 4741881. ture. The volume of slime produced after 3 days of incubation at $37^{\circ} \mathrm{C}$ in thioglycolate broth (Oxoid) was determined and was expressed as a percentage of the total volume of the culture after centrifugation at $1,500 \times g$ for $10 \mathrm{~min}$. The annular radii of the hemolysis zones around streaks and colonies of the isolates were measured and compared after duplicate plates were incubated at 37 and $27^{\circ} \mathrm{C}$ for 2 to 3 days on bovine, ovine, and equine blood agar media. The isolates were also tested for their ability to grow on blood agar containing polymyxin B $(1,000 \mathrm{IU} / \mathrm{ml}$; Oxoid). Motility was determined after stab inoculation into semisolid motility medium (17). The amount of radial extension of haze from the stab line and the level of zoospore activity observed microscopically in wet mounts were measured after incubation at 37 and $27^{\circ} \mathrm{C}$. Susceptibility to penicillin $\mathrm{G}(10 \mathrm{U})$, streptomycin $(10 \mu \mathrm{g})$, tetracycline $(30 \mu \mathrm{g})$, neomycin (30 $\mu \mathrm{g})$, chloramphenicol $(30 \mu \mathrm{g})$ and sulfafurazole $(100 \mu \mathrm{g})$ was determined by the standard single-disc method $(4,5)$, with the following two modifications: the Dermatophilus isolates were tested on Mueller-Hinton agar supplemented with $9 \%$ bovine blood, and the annular radii of the zones obtained with the isolates were measured after $48 \mathrm{~h}$ of incubation. We also determined the antibiotic susceptibility of W8 and W11 at $27^{\circ} \mathrm{C}$. Reference organisms Escherichia coli NCTC 10418 and Staphylococcus aureus NCTC 6571 were treated as they are treated in standard tests.

Morphological characteristics. Zoospore suspensions in distilled water were prepared by using growth harvested from cultures on blood agar after 3 days of incubation at $37^{\circ} \mathrm{C}$ and $\geq 8$ days of incubation at room temperature to promote caseous colonies. The zoospores were examined with a transmission electron microscope after negative staining with $2 \%$ phosphotungstic acid. Observations of flagella and other features were recorded, and representative zoospores were photographed for measurements.

Morphological features of mature filaments after growth in thioglycolate broth were highlighted by negative staining with India ink (7), and samples were photographed with an Olympus Vanox microscope. Capsular thickness was measured by using the photographic prints and the final magnification of each print. The mean of two to seven measurements was recorded for each isolate.

Air-dried, acetone-fixed smears of $D$. congolensis zoospores were stained by using an indirect fluorescent-antibody procedure and monoclonal antibody $2 F_{4}$ (11). This monoclonal antibody reacts with $D$. congolensis zoospore surface antigen. The smears were examined to determine the fluorescent staining pattern and intensity. The microscopic appearance after Gram staining and ZiehlNeelsen staining for acid fastness (7) was also examined.

Biochemical characterization. Catalase and urease tests were performed as previously described (12). The proteolysis test media used were nutrient gelatin medium (128 g/liter; Oxoid) and litmus milk medium (10\% skim milk powder, $1.2 \%$ litmus solution). Tests for gelatin hydrolysis (method 2 ), methyl red and Voges-Proskauer reactions, nitrate reduction, indole production (method 2), and acid production from sugars in cystine tryptic medium (Gibco) were performed as described by Cowan (7).

Isolates were screened for various enzyme activities by using a gel diffusion technique (9), as follows. Suspensions of zoospores in peptone water were 
prepared from caseous or mucoid growth harvested from cultures on bovine blood agar after $\geq 4$ days of incubation at $27^{\circ} \mathrm{C}(12,24)$. The suspensions were incubated in 4-mm-diameter wells in $1 \%$ agarose gels containing substrates (see below). The chondroitinase substrates, which were dissolved at a concentration of $0.1 \mathrm{mg} / \mathrm{ml}$ in phosphate-buffered saline ( $\mathrm{pH} \mathrm{7.5)} \mathrm{containing} 1 \%$ Ultra pure DNA grade agarose (Bio-Rad Laboratories, Richmond, Calif.), were chondroitin 4-sulfate, chondroitin 6-sulfate (Sigma Chemical Co., St. Louis, Mo.), and sheep dermatan sulfate (kindly provided by the Animal Products Technology Branch of the Department of Agriculture, Western Australia). Duplicate plates were incubated at 37 and $27^{\circ} \mathrm{C}$ for 24 to $48 \mathrm{~h}$. The gels were stained with $0.02 \%$ toluidine blue (Gurr Biological Stains, Chadwell Heath, Essex, England) in $0.1 \mathrm{M}$ acetic acid, and the sizes of cleared zones were measured after the preparations were destained with $0.1 \mathrm{M}$ acetic acid. The hyaluronidase substrate used was hyaluronic acid (rooster comb; $0.2 \mathrm{mg} / \mathrm{ml}$; Sigma). The gels were stained as described above for the chondroitins, but were destained for 30 min with $0.05 \mathrm{M}$ acetic acid and several times with distilled water. Human testicular hyaluronidase (Sigma), chondroitinase AC (catalog no. C-2262; Sigma), and chondroitinase $\mathrm{ABC}$ (catalog no. C-3509; Sigma) dilutions were used as standards. The protease substrate, $0.5 \%(\mathrm{wt} / \mathrm{vol})$ skim milk powder in peptone water-1\% agarose, was stained with $0.01 \%$ Coomassie brilliant blue R250. Lipase activity was determined by using a nutrient agar medium containing emulsified $1 \%$ tributyrin and $1 \%$ Tween $80(35)$ at three temperatures: $37^{\circ} \mathrm{C}$ for 4 days, $27^{\circ} \mathrm{C}$ for 6 days, and room temperature for 7 days. Lipase 448 (Nutritional Biochemicals Corp.) was used as the standard.

A collagenase substrate, acid-soluble collagen $(1 \mathrm{mg} / \mathrm{ml})$ prepared from sheep skin, was kindly provided by the.Animal Products Technology Branch of the Western Australia Department of Agriculture. After dialysis at $4^{\circ} \mathrm{C}$ against phosphate-buffered saline ( $\mathrm{pH} 7.5$ ), this collagen is soluble at $4^{\circ} \mathrm{C}$, but it forms a gel at $37^{\circ} \mathrm{C}$. The soluble collagen was pipetted $\left(80 \mu \mathrm{l}\right.$ per well) at $4^{\circ} \mathrm{C}$ into sterile microtiter plates (Flow Laboratories), and the resulting preparations were incubated at $37^{\circ} \mathrm{C}$ overnight to allow the collagen to solidify. Suspensions of Dermatophilus isolates in peptone water $\left(10 \mu \mathrm{l}\right.$ per well; $4 \times 10^{6}$ to $2 \times 10^{7} \mathrm{CFU}$ per well) were pipetted into the centers of the gels. Collagenase A (Boehringer Mannheim, North Ryde, New South Wales, Australia) diluted in phosphatebuffered saline ( $\mathrm{pH} 7.5$ ) supplemented with $0.9 \mathrm{mM} \mathrm{Ca}^{2+}, 0.5 \mathrm{mM} \mathrm{Mg}^{2+}$, and 1 $\mathrm{mM} \mathrm{Zn}{ }^{2+}$ was used as the standard. The plates were incubated at 37 and $27^{\circ} \mathrm{C}$ and observed daily for 10 days; the experiment was repeated three times. In the presence of collagenase, the collagen gel liquified. The liquified gel from positive wells was compared with collagen gel obtained from negative wells by electron microscopy. The samples were acidified with 4 volumes of $0.1 \mathrm{M}$ acetic acid and dialyzed against 50 volumes of $0.4 \%$ ATP in $0.1 \mathrm{M}$ acetic acid for $48 \mathrm{~h}$ at $4^{\circ} \mathrm{C}$. Samples were dried on Formvar grids, negatively stained with $2 \%$ phosphotungstic acid, and examined by transmission electron microscopy for the presence of segment long-spacing aggregates (arrays of aligned collagen molecules), as described by Snowden and Swann (31).

An elastase screening method, in which elastin-Congo red (catalog no. E-0502; Sigma) was used, was adapted for microtiter plates from the method of Shotton (29). An elastin-Congo red suspension (1 or $4 \mathrm{mg} / \mathrm{ml}$ ) and a suspension of Dermatophilus zoospores $\left(10^{8}\right.$ to $\left.10^{9} \mathrm{CFU} / \mathrm{ml}\right)$ in broth were dispensed into each well. Dilutions of elastase (Boehringer Mannheim) in broth were used as the standards. The following five diluents for suspending elastin-Congo red were compared: $0.02 \mathrm{M}$ borate buffer ( $\mathrm{pH} 8.8$ ), borate buffer-peptone water (1:1, $\mathrm{vol} / \mathrm{vol}$ ), phosphate-buffered saline, peptone water, and $0.067 \mathrm{M}$ phosphate buffer ( $\mathrm{pH} 7.5$ ). Duplicate plates were incubated at room temperature and at $27^{\circ} \mathrm{C}$ and were observed daily for 7 to 14 days for release of Congo red from the elastin particles.

Restriction enzyme analysis of bacterial DNA. DNAs were extracted from the Dermatophilus isolates by a method adapted from the method of Wilson (36). Restriction enzyme analysis with $A p a \mathrm{I}, B a m \mathrm{HI}$, and PvuII was performed as described by Sambrook et al. (27). These restriction enzymes were chosen because they differentiated groups of $D$. congolensis isolates in other studies ( 9 , 34). Digests were electrophoresed in $0.7 \%$ Ultra pure DNA grade agarose (Bio-Rad Laboratories) in Tris-borate-EDTA buffer at $2.7 \mathrm{~V} / \mathrm{cm}$ for $4 \mathrm{~h}$. The gels were stained with a solution containing $0.1 \mu \mathrm{g}$ of ethidium bromide per ml and were photographed with Polaroid type 667 film under UV light.

Bacterial protein characterization. Dermatophilus isolates were harvested from low-protein nutrient agar containing $1 \%$ tryptone, $0.5 \% \mathrm{NaCl}, 1.75 \%$ casein hydrolysate, and $0.015 \%$ soluble starch after incubation for 4 to 5 days at $27^{\circ} \mathrm{C}$, suspended in normal saline, and heated at $56^{\circ} \mathrm{C}$ for $6 \mathrm{~h}$ to release protein from the cells. Native protein polyacrylamide gel electrophoresis (PAGE) and sodium dodecyl sulfate (SDS)-PAGE were performed with a Phast System apparatus (Pharmacia) by using 8 to $25 \%$ gradient polyacrylamide gels at $150 \mathrm{~V}$, $3 \mathrm{~mA}, 1.5 \mathrm{~W}$, and $15^{\circ} \mathrm{C}(105 \mathrm{~V}-\mathrm{h}$ for SDS-PAGE and 150 to $160 \mathrm{~V}$-h for native protein PAGE). The gels were stained by using the Phast System silver staining procedures and photographed.

Infectivity in sheep, guinea pigs, and rabbits. Infectivity studies were conducted with the approval of the Animal Experimentation Ethics Committee of the Department of Agriculture, Western Australia. Suspensions of zoospores of each isolate containing $10^{5}, 10^{6}, 10^{7}$, and $10^{8} \mathrm{CFU} / \mathrm{ml}$ of peptone water and a peptone water control were inoculated onto white rabbits that weighed approximately $3 \mathrm{~kg}$ (body weight) guinea pigs that were at least 12 weeks old, and sheep (weaner wethers). The back of each animal was closely clipped over an area extending on each side of the midline. The area was swabbed with a cotton wool pad soaked in soapy water and then washed with ether to remove the surface lipids. Five sites ( 4 by $4 \mathrm{~cm}$ for sheep, 2.5 by $2.5 \mathrm{~cm}$ for rabbits, and 2.5 by $2 \mathrm{~cm}$ for guinea pigs) were marked on each back. Inoculation was performed by immersing a cotton wool swab in a zoospore suspension or peptone water control and rolling it across a site for $1 \mathrm{~min}$. The swab was weighed before and after application to ascertain the volume of suspension applied to the site and hence the approximate number of Dermatophilus zoospores. The sites were examined 3 , $5,7,10,12$, and 14 days after inoculation by a single operator and scored for severity as described by Sanders et al. (28), but on a scale of 0 to 5 . The lesion score for each site was calculated as follows: lesion score $=$ lesion severity $\times$ percentage of area affected.

For each isolate on each day of examination, a quadratic regression was fitted between the $\log _{10}$ number of zoospores applied and the lesion score in order to estimate adjusted lesion scores at the standard doses $\left(10^{4}, 10^{5}, 10^{6}\right.$, and $10^{7}$ $\mathrm{CFU} / \mathrm{ml}$ ). A nonhierarchial cluster analysis was carried out to group the isolates into virulence categories for each animal species, as described previously (9).

\section{RESULTS}

Cultural characteristics. All three chelonid Dermatophilus isolates produced discrete colonies at both 37 and $27^{\circ} \mathrm{C}$ on bovine blood agar and polymyxin blood agar, but all three isolates grew faster at $27^{\circ} \mathrm{C}$ than at $37^{\circ} \mathrm{C}$. At $37^{\circ} \mathrm{C}$, they produced small, dry, adherent, very slightly raised, grey-white colonies after 3 days. After transfer to room temperature, the colonies were white, raised, and umbonate or annelliform and became sticky after several days and then caseous after prolonged storage. At $27^{\circ} \mathrm{C}$, the colonies were adherent, raised, white, and larger than the colonies produced at $37^{\circ} \mathrm{C}$. Colonies changed from dry to sticky more rapidly when the initial growth was at $27^{\circ} \mathrm{C}$. At $37^{\circ} \mathrm{C}$, colonies of all three isolates were surrounded by zones (annular radii, $<1 \mathrm{~mm}$ ) of beta-hemolysis as defined by Cowan (7), with outer zones (annular radii, 5 to $6 \mathrm{~mm}$ ) of greenish alpha-hemolysis. After growth at $27^{\circ} \mathrm{C}$, the isolates exhibited only beta-hemolysis. On ovine blood agar, the isolates produced $0.5-$ to $1-\mathrm{mm}$ zones of beta-hemolysis at $37^{\circ} \mathrm{C}$ and $1-\mathrm{mm}$ zones at $27^{\circ} \mathrm{C}$, while on equine blood agar they produced little or no hemolysis at $37^{\circ} \mathrm{C}$ and $<0.5-\mathrm{mm}$ hemolysis zones at $27^{\circ} \mathrm{C}$. During prolonged incubation ( 3 to 6 weeks) at room temperature on the tryptone-casein hydrolysate agar used for bacterial protein characterization, proliferation continued, and raised, sticky, ivory-colored growth having a rubbery texture was produced. Strain W8, W11, and W16 $6^{\mathrm{T}}$ cultures produced a distinctive putrid odor.

In thioglycolate broth, all three isolates produced transparent slime which accounted for approximately $12 \%$ of the culture volume. In tryptose-phosphate- $10 \%$ ovine serum broth, all three isolates produced a flocculent deposit and a clear supernatant, and there was no growth at the surface or suspended in the broth.

Susceptibility tests revealed that the three chelonid isolates were resistant to streptomycin $(10 \mu \mathrm{g})$ and neomycin $(30 \mu \mathrm{g})$ (annular radii of zones, $\leq 4 \mathrm{~mm}$; annular radii of $\geq 6 \mathrm{~mm}$ indicate susceptibility $[4,5])$ at 37 and $27^{\circ} \mathrm{C}$ and susceptible to penicillin $\mathrm{G}(10 \mathrm{U})$, tetracycline $(30 \mu \mathrm{g})$, chloramphenicol ( 30 $\mu \mathrm{g}$ ) and sulfafurazole $(100 \mu \mathrm{g}$ ) (annular radii, 22 to $31 \mathrm{~mm}$ ). Zoospores of all three isolates exhibited limited motility at both 37 and $27^{\circ} \mathrm{C}$.

Morphological characteristics. Electron microscopic examination of the zoospores revealed that the number of flagella per zoospore varied within samples, with most zoospores having no flagella but some zoospores having up to six. The zoospore sizes ranged from 0.7 by $0.8 \mu \mathrm{m}$ (minimum diameter by maximum diameter) to 1.2 by $1.6 \mu \mathrm{m}$. In thioglycolate broth inoculated with zoospores coccoid and long club-shaped forms predominated after $24 \mathrm{~h}$. Over a period of several days, the club-shaped germ tubes elongated to filaments, eventually 
a

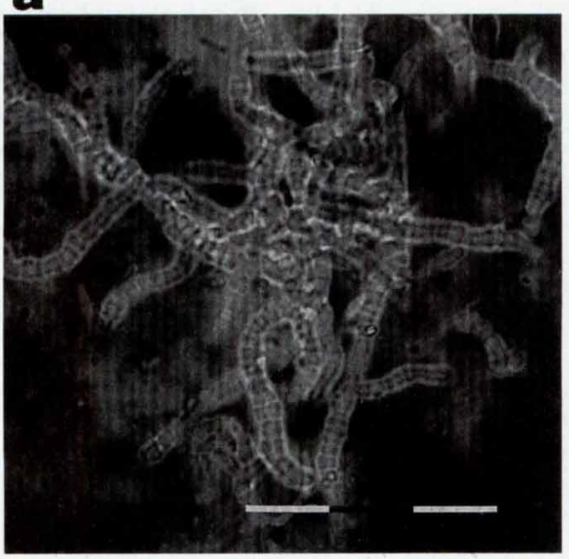

c

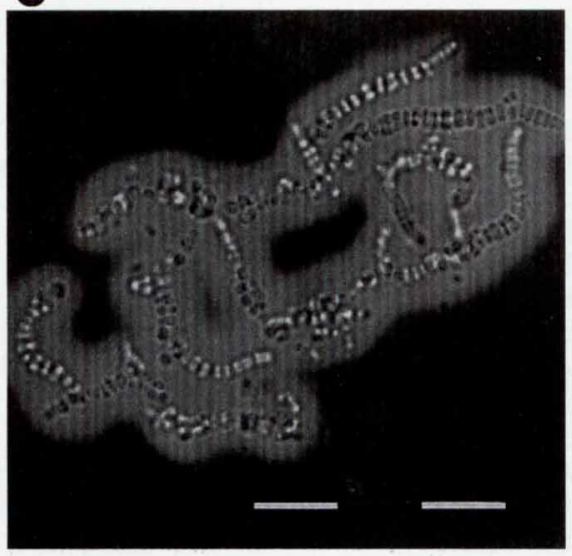

e

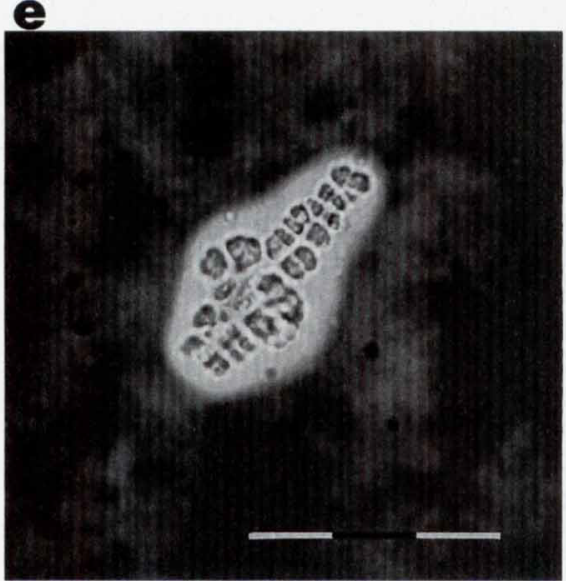

b

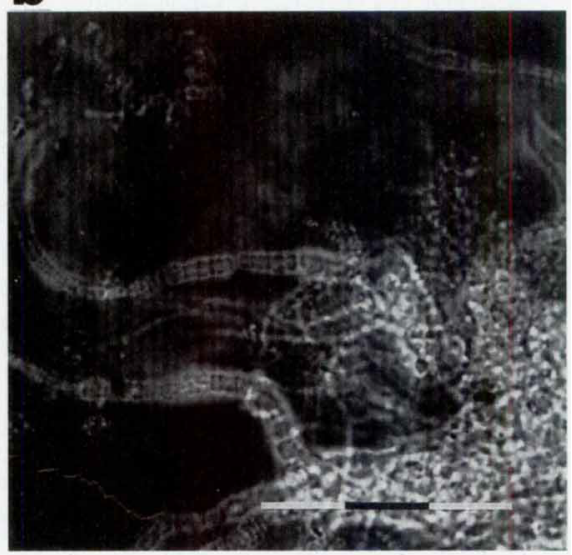

d

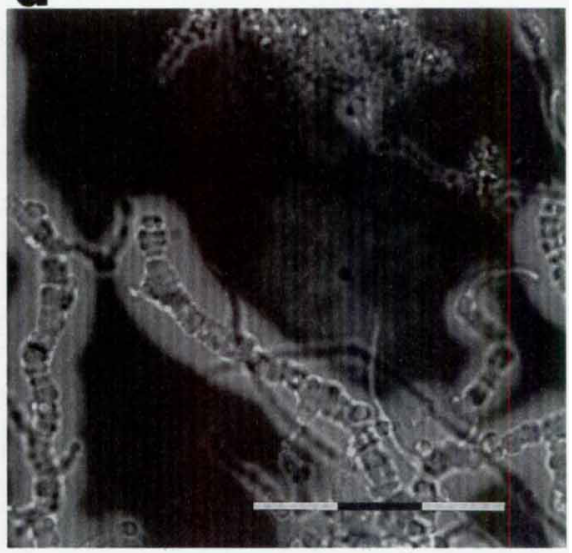

f

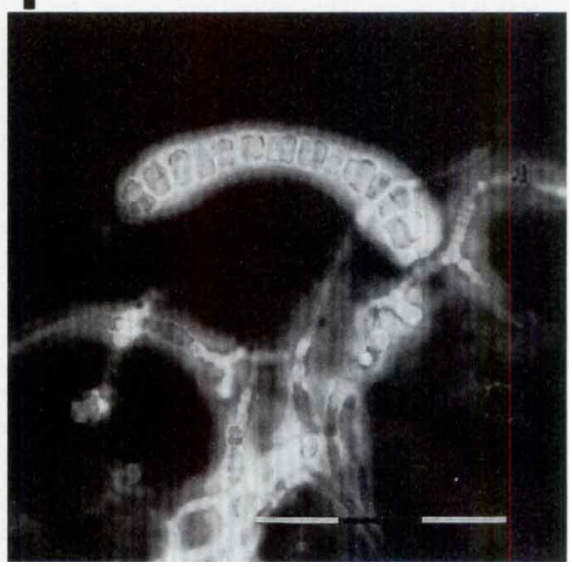

FIG. 1. Capsules around mature filaments of Dermatophilus isolates. (a) Tortoise isolate W8. (b) Snapping turtle isolate W16 ${ }^{\mathrm{T}}$. (c to f) Mammalian D. congolensis strains W3, S2, MB, and W15. The cultures were negatively stained with India ink. On each scale bar 1 division $=10 \mu \mathrm{m}$.

producing branching mycelia. Septa formed initially transversely with a slight bulging of the filament on one side of the septum. After prolonged incubation when a small inoculum was used, some mycelia had transverse and longitudinal septa at regular intervals; this created an appearance of cuboidal packets of spores within the mature filaments (Fig. 1). With a large inoculum in tightly capped tubes, we observed no septa other than the transverse septa. The mean thicknesses of the capsules around the mature filaments were $0.13 \mu \mathrm{m}$ for $\mathrm{W} 8$, $1.3 \mu \mathrm{m}$ for $\mathrm{W} 11$, and $0.5 \mu \mathrm{m}$ for $\mathrm{W} 16^{\mathrm{T}}$ (Fig. 1). Only three mammalian isolates had capsules that were $\leq 2 \mu \mathrm{m}$ thick. Fluorescent-antibody staining with monoclonal antibody $2 \mathrm{~F}_{4}$ was negative for all three chelonid isolates. Gram-stained smears contained gram-positive coccoid forms, germ tubes, and branching filaments with transverse and longitudinal divisions. Transverse rows containing up to five zoospores were 
TABLE 1. Comparison of chelonid Dermatophilus isolates with $D$. congolensis isolates ${ }^{a}$

\begin{tabular}{|c|c|c|}
\hline Category & $\begin{array}{c}\text { Characteristics common to chelonid isolates and } \\
\text { D. congolensis isolates }\end{array}$ & $\begin{array}{l}\text { Distinctive characteristics of chelonid isolates } \\
\text { W8, W11, and W16 } 6^{\mathrm{Tb}}\end{array}$ \\
\hline Morphology & $\begin{array}{l}\text { Gram-positive branching filaments which divide } \\
\text { by transverse and longitudinal septa to form } \\
\text { zoospores, which form germ tubes, elongate } \\
\text { into filaments, and repeat the cycle; zoospore } \\
\text { size; not acid fast }\end{array}$ & $\begin{array}{l}\text { Thin capsules around mature filaments; } \\
\text { not reactive with monoclonal } \\
\text { antibody } 2 \mathrm{~F}_{4} \text {; few flagella per } \\
\text { zoospore }\end{array}$ \\
\hline Cultural & $\begin{array}{l}\text { Growth on blood agar initially dry and } \\
\text { adherent; later growth is moist, especially at } \\
\leq 30^{\circ} \mathrm{C} \text {; beta-hemolysis on bovine blood agar } \\
\text { at } 27^{\circ} \mathrm{C} \text {; colony morphology; resistant to } \\
\text { polymyxin B; susceptible to penicillin } \mathrm{G}, \\
\text { tetracycline, chloramphenicol, and } \\
\text { sulfafurazole }\end{array}$ & $\begin{array}{l}\text { Growth faster at } 27^{\circ} \mathrm{C} \text { than at } 37^{\circ} \mathrm{C} ; \\
\text { sticky (not mucoid) growth on agar } \\
\text { media after prolonged incubation at } \\
\leq 30^{\circ} \mathrm{C} \text {; two hemolysis zones on } \\
\text { bovine blood agar at } 37^{\circ} \mathrm{C} \text { in the } \\
\text { presence of } 10 \% \mathrm{CO}_{2} \text { (inner beta- } \\
\text { hemolysis zone and outer alpha- } \\
\text { hemolysis zone); low motility; } \\
\text { resistant to streptomycin and } \\
\text { neomycin }\end{array}$ \\
\hline Genomic & & $\begin{array}{l}\text { Multilocus enzyme electrophoretic } \\
\text { type } \\
\text { Restriction enzyme analysis } \\
\text { electrophoretic patterns }\end{array}$ \\
\hline Infectivity & & $\begin{array}{l}\text { Low infectivity in sheep, rabbits, and } \\
\text { guinea pigs }\end{array}$ \\
\hline Biochemical $^{d}$ & $\begin{array}{l}\text { Catalase positive; gelatin and casein hydrolyzed; } \\
\text { acid produced from glucose; no acid } \\
\text { produced from sucrose, trehalose, dulcitol, } \\
\text { xylose, lactose, mannitol, sorbitol, or salicin; } \\
\text { indole not formed; chondroitinase activity } \\
\text { against chondroitin 4-sulfate; no } \\
\text { hyaluronidase or elastase activity detected; } \\
\text { methyl red and Voges-Proskauer tests } \\
\text { negative }\end{array}$ & $\begin{array}{l}\text { Nitrate weakly reduced to nitrite; } \\
\text { collagenase activity (in vitro); native } \\
\text { and SDS protein PAGE patterns; } \\
\text { urease negative (strains W8 and } \\
\text { W11); distinctive odor of cultures }\end{array}$ \\
\hline
\end{tabular}

\footnotetext{
${ }^{a}$ Data from references $8,9,12$, and 14 .

${ }^{b}$ The following characteristics are observed infrequently in $D$. congolensis: thin capsules around mature filaments; few flagella per zoospore; and low motility.

${ }^{c}$ See reference 34 .

${ }^{d}$ In addition, acid is produced from fructose by $D$. congolensis and isolates W11 and W16 ${ }^{\mathrm{T}}$ but not by isolate W8, from maltose by $D$. congolensis and isolate W16 ${ }^{\mathrm{T}}$, and from galactose by $D$. congolensis and isolate $\mathrm{W} 16^{\mathrm{T}}$; acid is produced variably from galactose by isolates W8 and W11.
}

seen in mature filaments. The organisms were not acid fast as determined by Ziehl-Neelsen staining.

Biochemical characterization. The three chelonid Dermatophilus isolates were catalase positive, produced acid from glucose, hydrolyzed gelatin, and degraded casein in litmus milk. They showed evidence of protease activity in a skim milk gel diffusion assay and exhibited chondroitinase activity against chondroitin 4-sulfate, but not against chondroitin 6-sulfate or dermatan sulfate. No hyaluronidase or elastase activity was detected. Isolate $\mathrm{W} 16^{\mathrm{T}}$ produced acid from maltose; W8 and W11 exhibited variable acid production from galactose, but $\mathrm{W} 16^{\mathrm{T}}$ was consistently positive. $\mathrm{W} 11$ and $\mathrm{W} 16^{\mathrm{T}}$ produced acid from fructose, but W8 did not. Isolates W8 and W11 lacked urease activity. All three chelonid isolates reduced nitrate and exhibited lipase activity on tributyrin agar, with larger zone diameters at room temperature and at $27^{\circ} \mathrm{C}$ than at $37^{\circ} \mathrm{C}$. The three isolates consistently liquified collagen gel at 27 and $37^{\circ} \mathrm{C}$. Collagen breakdown was confirmed by electron microscopy before and after incubation with the isolates, demonstrating the disappearance of segment long-spacing monomers (Table 1).

Restriction enzyme analysis of bacterial DNA. The chelonid isolates produced identical electrophoretic profiles that were distinct from those of $D$. congolensis with enzymes ApaI, $B a m \mathrm{HI}$, and PvuII (Fig. 2).

Bacterial protein characterization. The SDS-PAGE profiles of the three chelonid isolates were identical (data not shown), while the native protein PAGE profiles of the chelonid isolates were similar. In both cases the profiles were different from the profiles of $D$. congolensis strains (Fig. 3).

Infectivity in sheep, rabbits, and guinea pigs. All three chelonid isolates produced minimal dermatophilosis lesions which resolved by 7 days after inoculation onto sheep, rabbits, and guinea pigs.

\section{DISCUSSION}

In this paper we describe the first isolates of Dermatophilus sp. obtained from tortoises or turtles. The mode of transmission of the bacteria to the chelonids is not known. Dermatophilus sp. was not isolated from water and soil samples collected on site at the same time that strain $\mathrm{W} 16^{\mathrm{T}}$ was isolated (32). Other reports of Dermatophilus strains obtained from reptiles include reports of six isolates obtained from lizards (2, $6,23,30)$. After experimental inoculation, two of the lizard isolates were pathogenic, one for lizards and mice (2) and another for a sheep (30). The lesions on the sheep resulting from experimental infection with the lizard isolate were more severe and persistent than the lesions caused by the chelonid isolates in this study, although the inoculation procedures differed. Two of the lizard isolates were urease negative $(2,23)$; one of these isolates produced acid from mannitol (2), while the other fermented sucrose and was resistant to penicillin, lincomycin, and triple sulfonamides (23). A third lizard isolate was resistant to neomycin and sulfonamides (30). Other pre- 


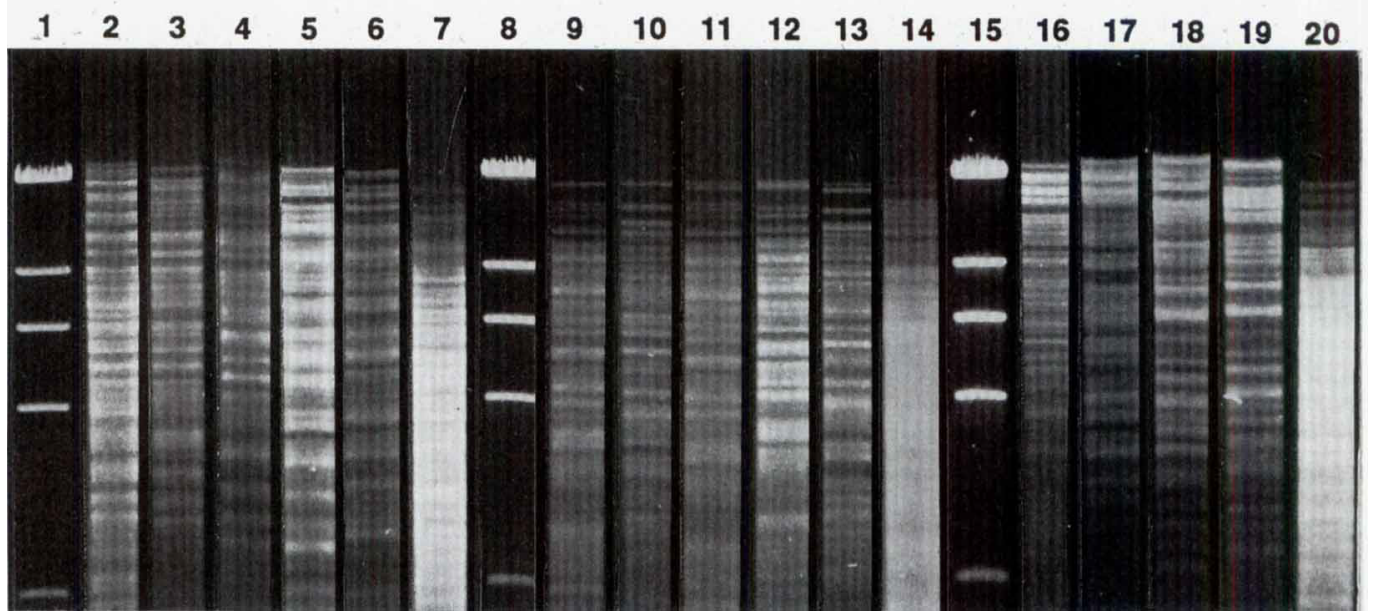

FIG. 2. Restriction enzyme analysis of bacterial DNAs. The electrophoretic patterns of restriction enzyme digests of DNAs from representative mammalian $D$. congolensis strains were identified by using enzymes $A p a \mathrm{I}, B a m \mathrm{HI}$, and PvuII and were compared with the electrophoretic patterns of a representative turtle Dermatophilus isolate. Lanes 2 through 6, Bam HI, mammalian strain groups 1 to 5, respectively; lane 7, Bam HI, turtle isolate W11; lanes 9 through 13, PvuII, mammalian strain groups 1,2 , and 4 to 6 , respectively (the mammalian group 3 pattern differs from the group 6 pattern by having one additional band in the 18,000 to 23,000-bp range); lane 14, PvuII, W11; lanes 16 through $19, A p a I$, mammalian strain groups 1 to 4 , respectively; lane 20 , ApaI, strain W11; lanes 1 , 8 , and 15, lambda DNA restricted with HindIII, which produced bands at (from top to bottom) $23,130,9,416,6,557,4,373$ and 2,322 bp. This figure is a composite of representative patterns cut out from photos of electrophoresis gels, with the magnifications equalized between 23,130 and 6,557 bp. In several lanes, the DNA fragments smaller than $6,557 \mathrm{bp}$ migrated at different rates, but retained the same pattern.

viously reported cultural, biochemical, and microscopic characteristics of the lizard isolates were similar to those of mammalian $D$. congolensis isolates. While the lizard isolates differed slightly from $D$. congolensis, they also differed from the chelonid isolates in cultural characteristics, in mannitol and sucrose test results, and in antibiotic resistance characteristics (except for neomycin resistance).

Many cultural, morphological, and biochemical characteristics of the chelonid Dermatophilus isolates and the mammalian D. congolensis strains were similar, but there were several important differences. Gordon (12) observed wide ranges of variation in colony morphology, pigmentation, acid production from maltose, proteolytic ability, degree of encapsulation, and

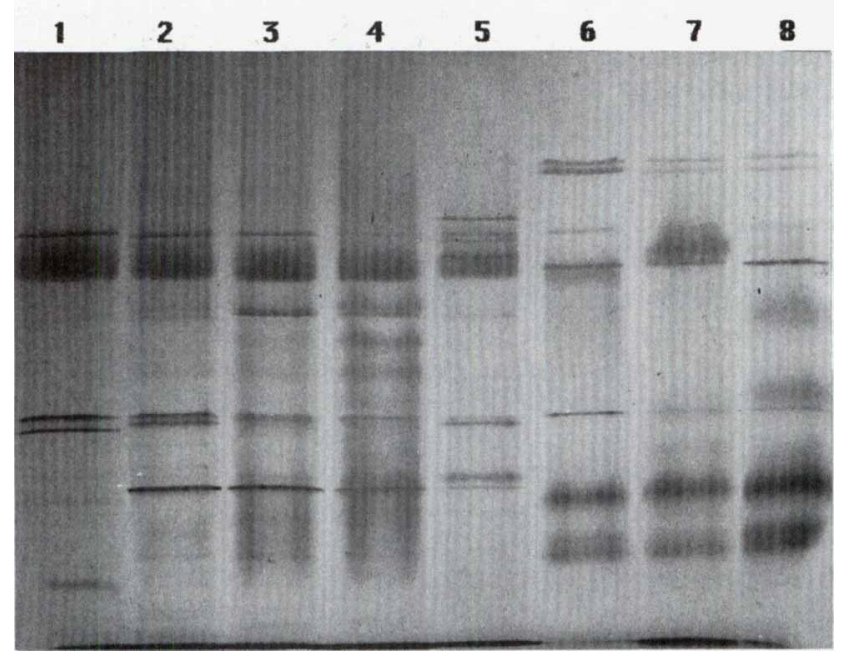

FIG. 3. Native protein PAGE profiles of protein extracts from $D$. congolensis strains representing five of the seven groups of mammalian strains (lanes 1 through 5) and chelonid isolates W8, W11, and W16 ${ }^{\mathrm{T}}$ (lanes 6 through 8 ). All of the mammalian isolates lacked the double band closest to the stacking gel and the set of diffuse bands which migrated farthest in the lanes containing proteins from the chelonid isolates. hemolysis under anaerobic growth conditions among $D$. congolensis isolates. Roberts described the plasticity of $D$. congolensis under different culture conditions, including inhibition of sporulation with reduced aeration $(24,26)$. Variation in antibiotic susceptibility among $D$. congolensis isolates, including resistance to streptomycin and neomycin, has been described by Elad and Yeruham (8). The variation and plasticity described above were considered when we compared the characteristics of the three chelonid Dermatophilus isolates with the characteristics of the mammalian $D$. congolensis strains. The ability of the chelonid isolates to grow faster at $27^{\circ} \mathrm{C}$ than at $37^{\circ} \mathrm{C}$ may reflect adaptation to poikilothermic hosts in a cool aquatic environment, and their sticky slime may improve adhesion to the host's skin in water. The difference in the hemolysis patterns may be linked to pathogenicity and awaits further investigation. The odor of cultures of the chelonid isolates differed from the odor of cultures of the mammalian D. congolensis strains, indicating that different metabolic product(s) may be present. The lack of fluorescent-antibody staining with monoclonal antibody $2 \mathrm{~F}_{4}$ indicates that the chelonid isolates lack a characteristic $D$. congolensis cell wall antigen. The poor motility and low number of flagella on the zoospores of the chelonid Dermatophilus isolates which we observed contrasted with the characteristics of most mammalian $D$. congolensis strains examined (9). It is possible that the chelonid isolates express flagella and exhibit greater motility under culture conditions different from the conditions used in this study. In tryptose-phosphate-10\% ovine serum broth $D$. congolensis isolates usually produce a layer of growth or a distinct pellicle at or near the surface, a suspended network of tiny colonies joined by fine filaments, and a flocculent deposit, whereas cultures of the chelonid isolates lack surface growth. This may indicate an absence of aerotaxis (25) or may reflect the poor motility of the zoospores in culture.

The rapid resolution of lesions (by 7 days) observed with the chelonid Dermatophilus isolates on three mammalian species differs from the resolution of lesions observed with mammalian D. congolensis strains, which produce lesions that are most severe at days 5 and 7 on guinea pigs and rabbits, respectively, 
and at days 12 to 14 on sheep (9). This may be due to the slower growth of the chelonid isolates at higher temperatures and adaptation to chelonid hosts. Maung (22) demonstrated that the tortoise Testudo ibera produced antibody against Brucella abortus very slowly compared with mammals.

Our restriction enzyme analysis of bacterial DNAs revealed that there is a genetic difference between the chelonid isolates and the mammalian strains of $D$. congolensis, but it is difficult to assess degrees of relatedness by this technique. Using multilocus enzyme electrophoresis, Trott et al. (34), compared allozymes of Dermatophilus isolates at 16 enzyme loci. At 11 of the loci investigated, the chelonid isolates had a different allele than any of the $D$. congolensis strains, including three American Type Culture Collection reference strains. The electrophoretic type of the chelonid isolates differed from the electrophoretic types of seven $D$. congolensis strains at an average of 13.6 loci, resulting in a calculated genetic distance of 0.852 . The high proportion of different allozymes is well within the range found previously to differentiate eukaryotic species within a genus $(3,15,20)$.

The results of cultural, morphological, and biochemical studies, including restriction enzyme analysis of bacterial DNAs and analysis of the PAGE patterns of bacterial proteins (see above), together with the genetic distances obtained in the study of Trott et al. (34), indicate that the chelonid isolates and D. congolensis strains belong to different species. We propose the name Dermatophilus chelonae for the chelonid isolates.

Description of Dermatophilus chelonae sp. nov. Dermatophilus chelonae (ke. lo'nae. L. gen. n. chelonae, of a turtle or tortoise, the source of the first isolates). Coccoid zoospores that are 0.7 by $0.8 \mu \mathrm{m}$ (minimum diameter by maximum diameter) to 1.2 by $1.6 \mu \mathrm{m}$ produce germ tubes (diameter, $\sim 1$ $\mu \mathrm{m})$ which elongate into filaments, eventually producing branching mycelia. Initially, septa form transversely, and there is a slight bulging of the filament on one side of the septum. Longitudinal septa are produced later, creating mature filaments with transverse and longitudinal divisions at regular intervals; the filaments are up to five cuboidal segments $(\sim 4$ $\mu \mathrm{m})$ in diameter and are surrounded by a thin capsule (thickness, 0.13 to $1.3 \mu \mathrm{m}$ ). The segments separate, becoming zoospores with zero to six flagella; aflagellate zoospores are the most common zoospores. All forms (zoospores, germ tubes, filaments, and segments) are gram positive. Not acid fast. Negative for fluorescent-antibody staining with monoclonal antibody $2 \mathrm{~F}_{4}(11)$.

Colonies on bovine blood agar after 3 days of growth are initially dry and adherent; the colonies are small, very slightly raised, and grey-white and have two hemolysis zones (beta and alpha) at $37^{\circ} \mathrm{C}$, and they are white, raised, and larger and have a beta-hemolysis zone at $27^{\circ} \mathrm{C}$. After transfer to room temperature, growth continues, and colonies are adherent, white, raised, and umbonate or annelliform; the colonies become sticky after several days and caseous after prolonged storage. On ovine blood agar, colonies are beta-hemolytic; on equine blood agar, colonies are nonhemolytic at $37^{\circ} \mathrm{C}$ and weakly beta-hemolytic at $27^{\circ} \mathrm{C}$. Good growth occurs on $1 \%$ tryptone$1.75 \%$ casein hydrolysate $-0.5 \% \mathrm{NaCl}$ agar, continuing for several weeks at room temperature. Cultures in tryptosephosphate-10\% ovine serum broth produce a flocculent deposit and a clear supernatant, and no growth is suspended or occurs at the surface. Cultures produce a distinctive putrid odor.

Acid is produced from glucose and is often produced from fructose and galactose (variable), as well as maltose. Acid is not produced from lactose, sucrose, xylose, dulcitol, mannitol, sorbitol, salicin, or trehalose.

Gelatin and casein are hydrolyzed. Catalase is produced.
Urease is not always produced. Weak reduction of nitrate to nitrite occurs. Indole is not formed; methyl red and VogesProskauer tests are negative. Chondroitinase activity occurs with chondroitin 4-sulfate but not with chondroitin 6-sulfate. Collagenase activity occurs with in vitro-assembled collagen.

Resistant to polymyxin B $(1,000 \mathrm{IU} / \mathrm{ml})$, streptomycin $(10$ $\mu \mathrm{g})$, and neomycin $(30 \mu \mathrm{g})$. Susceptible to penicillin $\mathrm{G}(10 \mathrm{U})$, tetracycline $(30 \mu \mathrm{g})$, chloramphenicol $(30 \mu \mathrm{g})$, and sulfafurazole $(100 \mu \mathrm{g})$

Differs from $D$. congolensis by electrophoretic detection of alleles for the following enzymes (34): phosphoglucose mutase, 6-phosphoglucose dehydrogenase, arginophosphokinase, catalase, superoxide dismutase, phosphoglucose isomerase, malate dehydrogenase, malic enzyme, nucleoside phosphorylase, leucine amino peptidase, and lactate dehydrogenase.

Isolated from chelonids with skin lesions or abscesses. Low levels of infectivity on sheep, rabbits, and guinea pigs.

The type strain is strain W16(= ATCC 51576).

\section{ACKNOWLEDGMENTS}

This research was supported by funds from the Wool Research Trust Fund of the Australian Wool Corporation.

We thank P. Ashley, D. Nelson, M. Kalkoven, and L. den Hollander for technical assistance. We are grateful to J. Snowden of the Animal Production Division of the Department of Agriculture, Western Australia, for technical advice.

\section{REFERENCES}

1. Abu-Samra, M. T., S. E. Imbabi, and E. S. Mahgoub. 1976. Dermatophilus congolensis. A bacteriological, in vitro histopathological study of natural infection in Sudanese cattle. Br. Vet. J. 132:627-631.

2. Anver, M. R., J. S. Park, and H. G. Rush. 1976. Dermatophilosis in the marble lizard (Calotes mystaceus) Lab. Anim. Sci. 26:817-823.

3. Ayala, F. J., and J. R. Powell. 1972. Allozymes as diagnostic characters of sibling species of Drosophila. Proc. Natl. Acad. Sci. USA 69:1094-1096.

4. Bauer, A. W., W. M. M. Kirby, J. C. Sherris, and M. Turck. 1966. Antibiotic susceptibility testing by a standardised single disc method. Am. J. Clin. Pathol. 45:493-496.

5. Bell, S. M. 1984. Antibiotic sensitivity testing by the CDS method. New South Wales Branch of the Australian Society for Microbiology, Melbourne

6. Chineme, C. N., and P. B. Addo. 1980. Pathologic changes in lizards (Agama agama) experimentally infected with Dermatophilus congolensis. J. Wildl. Dis. 16:407-412.

7. Cowan, S. T. 1974. Cowan and Steel's manual for the identification of medical bacteria, 2nd ed. Cambridge University Press, London.

8. Elad, D., and I. Yeruham. 1988. In vitro sensitivity to antimicrobial agents of Dermatophilus congolensis isolated from ruminants in Israel. Isr. J. Vet. Med. 44:134-136.

9. Ellis, T. M., A. M. Masters, S. S. Sutherland, J. M. Carson, and A. R. Gregory. 1993. Variation in cultural, morphological, biochemical properties and infectivity of Australian isolates of Dermatophilus congolensis. Vet. Microbiol. 38:81-102.

10. Ellis, T. M., S. S. Sutherland, and G. Davies. 1991. Strain variation in Dermatophilus congolensis demonstrated by cross-protection studies. Vet. Microbiol. 28:377-383.

11. Forbes, C. 1989. The production and use of monoclonal antibodies in a fluorescent antibody test for detection of Dermatophilus congolensis in the environment. B. S. Honours thesis. Department of Microbiology, University of Western Australia, Nedlands, Australia.

12. Gordon, M. A. 1964. The genus Dermatophilus. J. Bacteriol. 88:509-522.

13. Gordon, M. A. 1976. Characterization of Dermatophilus congolensis: its affinities with the Actinomycetales and differentiation from Geodermatophilus, p. 187-201. In D. H. Lloyd and K. C. Sellers (ed.), Dermatophilus infection in animals and man. Academic Press, London.

14. Gordon, M. A. 1989. Genus Dermatophilus Van Saceghem 1915, p. 2409 2410. In S. T. Williams, M. E. Sharpe, and J. G. Holt (ed.), Bergey's manual of systematic bacteriology, vol. 4. The Williams and Wilkins Co., Baltimore.

15. Holzschu, D. L., H. J. Phaff, and J. Tredick. 1983. Pichia pseudocactophila, a new species of yeast occurring in necrotic tissue of columnar cacti in the North American Sonoran Desert. Can. J. Microbiol. 29:1314-1322.

16. How, S. J., and D. H. Lloyd. 1990. The effect of recent vaccination on the dose-response to experimental Dermatophilus congolensis infection in rabbits. J. Comp. Pathol. 102:157-163.

17. Jordan, E. O., M. E. Caldwell, and D. Reiter. 1934. Bacterial motility. J. Bacteriol. 27:165-174 
18. Kwapinski, J. B., and G. C. Simmons. 1957. Serological and chemical properties of the Dermatophilus endoplasm. Antonie van Leeuwenhoek J. Microbiol. 33:100-106.

19. Kwapinski, J. B. G. 1969. Serological characteristics of particulate antigens of Dermatophilus. Can. J. Microbiol. 15:1141-1144.

20. Lee, J. I., D. J. Hampson, A. J. Lymbery, and S. J. Harders. 1993. The porcine intestinal spirochaetes: identification of new genetic groups. Vet. Microbiol. 34:273-285.

21. Macadam, I., and R. T. Haalstra. 1971. Bacteriology of Nigerian strains of Dermatophilus congolensis. Trop. Anim. Health Prod. 3:225-231.

22. Maung, R. T. 1963. Immunity in the tortoise Testudo ibera. J. Pathol Bacteriol. 85:51-66.

23. Montali, R. J., E. E. Smith, M. Davenport, and M. Bush. 1975. Dermatophilosis in Australian bearded lizards. J. Am. Vet. Med. Assoc. 167:533-555.

24. Roberts, D. S. 1957. Some features of the mycotic dermatitis organism. Aust. Vet. J. 33:141-143.

25. Roberts, D. S. 1963. Properties of Dermatophilus dermatonomus zoospores in relation to the transmission of mycotic dermatitis. Aust. J. Agric. Res. 14:373-385.

26. Roberts, D. S. 1963 . The influence of carbon dioxide on the growth and sporulation of Dermatophilus dermatonomus. Aust. J. Agric. Res. 14:412433.

27. Sambrook, J., E. F. Fritsch, and T. Maniatis. 1989. Molecular cloning: a laboratory manual, 2nd ed. Cold Spring Harbor Laboratory Press, Cold
Spring Harbor, N.Y.

28. Sanders, A. B., S. J. How, D. H. Lloyd, and R. Hill. 1990. The effect of energy malnutrition in ruminants on experimental infection with Dermatophilus congolensis. J. Comp. Pathol. 103:361-368.

29. Shotton, D. M. 1970. Elastase. Methods Enzymol. 19:113-140.

30. Simmons, G. C., N. D. Sullivan, and P. E. Green. 1972. Dermatophilosis in a lizard (Amphibolurus barbatus). Aust. Vet. J. 48:465-466.

31. Snowden, J. S., and D. A. Swann. 1980. Vitreous structure. V. The morphology and thermal stability of vitreous collagen fibres and comparison to articular cartilage (type II) collagen. Invest. Ophthalmol. Visual Sci. 19:610-618.

32. Sutherland, S. S. (Department of Agriculture, Western Australia). 1987. Personal communication.

33. Sutherland, S. S., T. M. Ellis, and J. R. Edwards. 1991. Evaluation of vaccines against ovine dermatophilus. Vet. Microbiol. 27:91-99.

34. Trott, D. J., A. M. Masters, J. M. Carson, T. M. Ellis, and D. J. Hampson. Genetic analysis of Dermatophilus spp. using multilocus enzyme electrophoresis. Zentralbl. Bakteriol., in press.

35. Willis, A. T. 1960. The lipolytic activity of some clostridia. J. Pathol. Bacteriol. 80:379-390.

36. Wilson, K. 1987. Preparation of genomic DNA from bacteria, p. 2.4.1-2.4.5 In F. M. Ausubel, R. Brent, R. E. Kingston, D. D. Moore, J. G. Seidman, J. A. Smith, and K. Struhl (ed.), Current protocols in molecular biology, vol. 1. John Wiley and Sons, New York. 